\title{
DAMPAK PAJANAN KEBISINGAN MESIN EXTRUDER TERHADAP GANGGUAN KOMUNIKASI PADA PEKERJA DI PT. X SIDOARJO
}

\author{
Aufrieda Ariestyajuni \\ Departemen Kesehatan Lingkungan, Fakultas Kesehatan Masyarakat \\ Universitas Airlangga Surabaya \\ Email: aufriedaa@gmail.com
}

\begin{abstract}
Exposure to extruder machine noise can cause non-auditory effects such as communication disorders. The purpose of this study was to analyze the effect of extruder machine noise exposure on the non-auditory effects of PT. X Sidoarjo in 2018. This research is an observational analytic study with cross sectional design. The research respondents were 60 people consisting of two groups, namely groups of workers in the extruder unit and office staff groups. The group of workers in the extruder unit is a group that is exposed to high noise while the office staff group is a control group that is exposed to low noise. Sampling is done by simple random sampling method. The independent variables in this study were the level of extruder machine noise exposure and the dependent variable in this study, which were non auditory effects which included communication disorders. Noise in the area of the extruder machine shows a number that exceeds the Threshold Value The limit is $85 \mathrm{dBA}$. The results of the questionnaire analysis showed that $81.6 \%$ of workers felt a communication disruption due to exposure to extruder machines at PT. X Sidoarjo. Efforts can be made to reduce the level of extruder noise exposure by the need for periodic engine maintenance, dampers to reduce the noise level of the extruder machine and work rotation is needed to reduce the impact of extruder machine noise exposure on workers.
\end{abstract}

Keywords: Noise, Extruder, Communication

\begin{abstract}
ABSTRAK
Pajanan kebisingan mesin extruder dapat menimbulkan efek non auditori berupa gangguan komunikasi. Tujuan dari penelitian ini adalah untuk menganalisis hubungan pajanan kebisingan mesin extruder terhadap efek non auditori pekerja PT. X Sidoarjo tahun 2018. Penelitian ini merupakan jenis penelitian observasional analitik dengan rancang bangun cross sectional. Responden penelitian berjumlah 60 orang yang terdiri dari dua kelompok yaitu kelompok pekerja di unit extruder dan kelompok staff kantor. Kelompok pekerja di unit extruder adalah kelompok yang terpajan bising tinggi sedangkan kelompok staff kantor adalah kelompok kontrol yang terpajan bising rendah. Pengambilan sampel dilakukan dengan metode simple random sampling. Variabel bebas dalam penelitian ini adalah tingkat pajanan kebisingan mesin extruder dan variabel terikat pada penelitian ini yaitu efek non auditori yaitu gangguan komunikasi. Kebisingan di area mesin extruder menunjukkan angka yang melebihi Nilai Ambang Batas yang ditetapkan yaitu 85 dBA. Hasil analisis kuesioner menunjukkan sebanyak $81,6 \%$ pekerja merasakan gangguan komunikasi akibat pajanan mesin extruder di PT. X Sidoarjo. Upaya yang dapat dilakukan untuk mengurangi tingkat pajanan kebisingan mesin extruder dengan cara perlu adanya perawatan mesin secara
\end{abstract}


berkala, peredam untuk menurunkan tingkat kebisingan mesin extruder serta perlu dilakukan rotasi kerja untuk mengurangi dampak dari pajanan kebisingan mesin extruder terhadap pekerja.

Kata kunci: Kebisingan, Extruder, Komunikasi.

\section{PENDAHULUAN}

Di era globalisasi seperti saat ini akan mendorong semakin meningkatnya kegiatan produksi dalam upaya pemenuhan permintaan masyarakat akan suatu barang. Diiringi dengan perkembangan jaman tentunya teknologi juga akan semakin canggih. Berbagai masalah lingkungan yang saat ini terjadi, ternyata disebabkan oleh perkembangan teknologi produksi untuk memenuhi kebutuhan masyarakat yang semakin kompleks.

Perusahaan PT. X merupakan perusahaan manufaktur yang bergerak di bidang produksi karung plastik atau benang karung yang berlokasi di Sidoarjo. Penggunaan teknologi canggih dan tenaga kerja yang berkualitas menjadikan perusahaan ini sangat kompetitif dalam harga dan dapat mengontrol kualitas. Kebisingan tersebut memiliki intensitas yang berbeda pada setiap mesin yang beroperasi. Berdasarkan laporan hasil pengujian yang dilakukan di PT. X pada Agustus 2017 menunjukkan pada lokasi Extruder memiliki intensitas kebisingan yang dapat dikategorikan cukup tinggi. Jenis kebisingan pada beberapa lokasi yang diukur, menunjukkan kebisingan yang kontinyu akibat pengoperasian mesin dilakukan selama 24 jam penuh setiap harinya. Selain membawa manfaat, perkembangan industri yang melaksanakan kegiatan produksi dengan kecanggihan teknologi yang digunakan ternyata juga menimbulkan berbagai masalah lingkungan salah satunya kebisingan. Kebisingan kontinyu yang terus menerus dapat memberikan dampak kesehatan pada pekerja terutama pada pendengaran. Berdasarkan Permenakertrans Nomor Per. 13/MEN/X/2011, tentang Nilai Ambang Batas Faktor Fisika dan Faktor Kimia di Tempat Kerja tidak diperbolehkan pemaparan selama 8 jam per hari dengan intensitas kebisingan $>85 \mathrm{~dB} .{ }^{1}$ Unit extruder di industri karung plastik ini merupakan lokasi produksi dari bahan mentah berupa biji plastik yang akan diubah menjadi bahan setengah jadi berupa helaian benang plastik. Helaian benang tersebut yang selanjutnya dipintal menjadi karung plastik. Dampak dari aktivitas produksi menggunakan mesin extruder setiap harinya akan menimbulkan bising terhadap aktivitas pekerja. Pekerja yang paling sering terpajan kebisingan ialah pekerja di unit extruder yang merupakan operator mesin. Peneliti memilih operator mesin sebagai subjek penelitian dikarenakan pekerja tersebut merupakan kelompok yang paling berisiko terkena dampak kebisingan dari pengoperasian mesin extruder di PT. X Sidoarjo. 


\section{METODE PENELITIAN}

Penelitian yang telah dilakukan ini merupakan jenis penelitian observasional dan analitik yang memiliki rancang bangun cross sectional study. Lokasi penelitian dilakukan di PT. X Sidoarjo pada bulan September 2018. Populasi penelitian ini adalah seluruh pekerja pada unit ekstruder PT. X Sidoarjo yang memenuhi kriteria inklusi diantaranya: sebelumnya tidak pernah bekerja di tempat yang bising; bekerja selama $\geq 8$ jam per hari dan bersedia menjadi responden. Besar sampel pada penelitian ini sebanyak 60 orang dengan teknik Simple Random Sampling pada pekerja di PT. $\mathrm{X}$ Sidoarjo. Pengukuran intensitas kebisingan menggunakan alat Sound Level Meter pada 6 titik di unit Extruder dan 10 titik di ruang kerja staff.

Variabel dalam penelitian ini diantaranya intensitas kebisingan dan karakteristik pekerja yang meliputi umur dan masa kerja. Penelitian ini telah lolos kaji etik dan mendapatkan sertifikat dari Komisi Etik Fakultas Kesehatan Masyarakat Universitas Airlangga nomor 385KEPK.

\section{HASIL DAN PEMBAHASAN}

\section{Karakteristik Responden}

Berdasarkan hasil penelitian yang telah dilakukan pada PT.X diperoleh data mengenai karakteristik reponden yang disajikan pada Tabel 1.
Tabel 1. Karakteristik Responden di PT. X Sidoarjo.

\begin{tabular}{lcc}
\hline Variabel & n & \% \\
\hline Usia & & \\
$\quad$ 25-40 tahun & 44 & 73,3 \\
$\quad>40$ tahun & 16 & 26,7 \\
\hline Jumlah & 60 & 100,0 \\
\hline Masa Kerja & & \\
$\quad \leq 10$ tahun & 35 & 58,3 \\
$\quad 11-20$ tahun & 25 & 41,7 \\
\hline Jumlah & 60 & 100,0 \\
\hline Pajanan Kebisingan & & \\
$\quad$ Tinggi $(>85 \mathrm{dBA})$ & 30 & 50,0 \\
$\quad$ Rendah $(\leq 85 \mathrm{dBA})$ & 30 & 50,0 \\
\hline Jumlah & 60 & 100,0 \\
\hline
\end{tabular}

Tabel 1 diatas menunjukkan distribusi karakteristik pekerja PT. X Sidoarjo. Diketahui usia pekerja paling banyak yaitu antara 25-40 tahun yang dapat dikategorikan sebagai usia produktif. Usia lebih tua relatif akan mengalami penurunan kepekaan terhadap rangsangan suara. Faktor usia harus diperhatikan sebagai salah satu faktor counfounding (perancu) yang penting. Perubahan pada fisiologis organ pendengaran manusia dapat menyebabkan terjadinya penurunan sensitifitas pendengaran seiring dengan bertambahnya usia seseorang. ${ }^{2}$ Penelitian yang dilakukan oleh Baktiansyah (2004) menunjukkan bahwa gangguan pendengaran lebih banyak terjadi pada pekerja yang berusia $>40$ tahun dan pekerja tersebut memiliki risiko sepuluh kali lebih besar bila dibandingkan dengan pekerja berusia $<40$ tahun. ${ }^{3}$ 
Dilihat pada variabel masa kerja sebagian besar pekerja pada PT. X Sidoarjo memiliki masa kerja $\leq 10$ tahun. Hal ini dikarenakan pekerja pada unit extruder ini merupakan pekerja kontrak sehingga memiliki masa kerja yang masih tergolong singkat dibanding pekerja pada unit lainnya di PT. X Sidoarjo. Pekerja memiliki risiko mengalami gangguan komunikasi selama bekerja apabila terpajan bising tinggi terus menerus. Adanya penurunan pendengaran yang ditandai dengan gangguan komunikasi tergantung dari lamanya pemaparan serta tingkat pajanan kebisingan yang diterima oleh pekerja tersebut.

Tingkat kebisingan yang diterima oleh pekerja pada PT. X Sidoarjo sebanyak 30 pekerja terpajanan kebisingan yang tergolong cukup tinggi yang mana tingkat kebisingan pada area extruder melebihi Nilai Ambang Batas yang telah ditetapkan oleh Permenakertrans Nomor Per. 13/MEN/X/2011, tentang Nilai Ambang Batas Faktor Fisika dan Faktor Kimia di Tempat Kerja. Sebanyak lebih dari $70 \%$ responden mengalami gangguan komunikasi berdasarkan hasil kuesioner. Gangguan komunikasi yang dialami oleh pekerja di PT. X Sidoarjo meliputi kendala dalam memahami perkataan orang lain sehingga memerlukan upaya berbicara dengan keras/lantang, mengulangi pembicaraan serta memerlukan bahasa isyarat ketika berkomunikasi selama bekerja di unit extruder.

\section{Tingkat Pajanan Kebisingan}

Tabel 2. Tingkat Pajanan Kebisingan Mesin Extruder di PT. X Sidoarjo.

\begin{tabular}{cccc}
\hline $\begin{array}{c}\text { Titik } \\
\text { Pengukuran }\end{array}$ & $\begin{array}{c}\text { Hasil } \\
(\mathrm{dBA})\end{array}$ & Kategori & Keterangan \\
\hline Titik I & 94 & $\begin{array}{c}\text { Bising } \\
\text { Tinggi }\end{array}$ & $\begin{array}{c}\text { Melebihi } \\
\text { Ambang } \\
\text { Batas }\end{array}$ \\
\hline Titik II & 75,94 & $\begin{array}{c}\text { Bising } \\
\text { Rendah }\end{array}$ & $\begin{array}{c}\text { Sesuai } \\
\text { Ambang } \\
\text { Batas }\end{array}$ \\
\hline
\end{tabular}

Kegiatan yang dilakukan di titik 1 yaitu produksi bahan mentah menjadi bahan setengah jadi yang berupa helaian benang plastik. Tingkat kebisingan pada titik I dapat dikategorikan sebagai bising tinggi yang melebihi Nilai Ambang Batas yang telah ditetapkan oleh Permenakertrans Nomor Per. 13/MEN/X/2011. Kegiatan pada titik 2 adalah penggulungan benang hasil dari produksi mesin extruder. Pada kegiatan penggulungan ini dilakukan dengan manual atau tanpa menggunakan mesin sehingga tingkat kebisingan pada area titik II tergolong bising rendah yang masih aman untuk memberikan pajanan terhadap pekerja selama 8 jam sehari.

\section{Gangguan Komunikasi}

Tabel 3. Distribusi Gangguan Komunikasi yang dialami oleh pekerja di PT. X Sidoarjo

\begin{tabular}{|c|c|c|}
\hline No. & Pertanyaan & $\%$ \\
\hline \multicolumn{3}{|l|}{1.} \\
\hline & $\begin{array}{l}\text { seıаma рекеrјa terganggu акıрал } \\
\text { suara dari mesin }\end{array}$ & 81,6 \\
\hline 2. & $\begin{array}{l}\text { Pekerja harus berteriak } \\
\text { (berbicara dengan nada tinggi) } \\
\text { jika sedang berbicara dengan } \\
\text { rekan kerja yang lain saat bekerja }\end{array}$ & 90,0 \\
\hline 3. & $\begin{array}{l}\text { Pekerja harus berteriak jika } \\
\text { sedang berbicara saat bekerja }\end{array}$ & 90,0 \\
\hline
\end{tabular}




\begin{tabular}{clc}
\hline No. & \multicolumn{3}{c}{ Pertanyaan } & $\%$ \\
\hline 4. & $\begin{array}{l}\text { Pekerja kurang paham dengan } \\
\text { apa yang diucapkan apabila tidak } \\
\text { memperhatikan mimik bibir } \\
\text { rekan kerjanya }\end{array}$ & 83,3 \\
\hline 5. & $\begin{array}{l}\text { Pekerja sering meminta rekan } \\
\text { kerjanya mengulangi kembali } \\
\text { perkataannya ketika sedang } \\
\text { berbicara saat bekerja karena }\end{array}$ & \\
& 75,0 \\
tidak mendengarnya & \\
\hline 6. & $\begin{array}{l}\text { Pekerja pernah ditegur oleh } \\
\text { rekan kerjanya saat bekerja, } \\
\text { karena kurang menangkap apa }\end{array}$ & \\
& yang dibicarakan \\
\hline 7. & $\begin{array}{l}\text { Pekerja ingin mengurangi } \\
\text { kebisingan di tempat bekerja }\end{array}$ & 65,0 \\
\hline 8. & $\begin{array}{l}\text { Pekerja akan meninggalkan } \\
\text { lingkungan bising tempat bekerja }\end{array}$ & 75,0 \\
& seandainya bisa \\
\hline
\end{tabular}

Distribusi gangguan komunikasi yang dialami oleh pekerja PT. X Sidoarjo diketahui sebanyak lebih dari $70 \%$ pekerja mengalami gangguan komunikasi. Gangguan komunikasi yang dialami hampir seluruh pekerja, meliputi pekerja harus berteriak (berbicara dengan nada tinggi) jika sedang berbicara dengan rekan kerja yang lain saat bekerja. Selain itu pekerja sering meminta rekan kerjanya mengulangi kembali perkataannya ketika sedang berbicara saat bekerja karena tidak mendengarnya serta pekerja pernah ditegur oleh rekan kerjanya saat bekerja, karena kurang menangkap apa yang dibicarakan sebesar 93,3\%. Gangguan komunikasi dapat berdampak pada produktifitas pekerja hingga menyebabkan kecelakaan kerja.

\section{SIMPULAN DAN SARAN}

\section{Simpulan}

1. Usia pekerja sebagian besar 25-40 tahun. Semakin bertambahnya usia seseorang akan memiliki risiko untuk mengalami penurunan pendengaran yang ditandai dengan adanya gangguan komunikasi.

2. Adanya penurunan pendengaran yang ditandai dengan gangguan komunikasi tergantung dari lamanya pemaparan serta tingkat pajanan kebisingan yang diterima oleh pekerja.

3. Gangguan komunikasi yang dialami oleh pekerja PT. X Sidoarjo diketahui sebanyak lebih dari $70 \%$ pekerja.

4. Upaya pencegahan dampak kebisingan terhadap timbulnya gangguan komunikasi pada pekerja dapat dilakukan diantaranya dengan upaya eleminasi sumber kebisingan serta adanya rotasi kerja.

\section{Saran}

1. Perlu dilakukan pemeriksaan secara berkala tingkat kebisingan yang ditimbulkan dari suara mesin extruder di PT. X Sidoarjo

2. Secara berkala 2 tahun sekali harus dilakukan pemeriksaan kesehatan pendengaran pekerja supaya dampak kebisingan mesin extruder dapat diminimalisir. 


\section{REFERENSI}

1. Kemenaker RI. Peraturan Menteri Tenaga Kerja No. PER. 13/MEN/X/2011 Tahun 2011 tentang Nilai Ambang Batas Faktor Fisika dan Faktor Kimia di Tempat Kerja. Jakarta: Setkab RI. 2011.

2. Primadona, A. Analisis Faktor Risiko yang Berhubungan dengan Penurunan Pendengaran pada Pekerja di PT. Pertamina Geothermal Energy Area Kamojang Tahun 2012. Universitas Indonesia. Depok. 2012.

3. Baktiansyah, A. Hubungan Merokok dengan Gangguan Pendengaran di Kalangan Pekerja Pria PT-X. Tesis.
Universitas Indonesia. Depok. 2004.

4. Rahmawati, D. Faktor-Faktor yang Berhubungan dengan Gangguan Pendengaran pada Pekerja di Departemen Metal Forming dan Heat Treatment PT. Dirgantara Indonesia (Persero) Tahun 2015. Universitas Islam Negeri Syarif Hidayatullah. Jakarta. 2015.

5. Riyan, M. Z. Rahayu, D. J. Kadarini, N. Dampak Kebisingan terhadap Komunikasi dan Konsentrasi Belajar Siswa Sekolah pada Jalan Padat Lalu Lintas. Universitas Tanjungpura. Pontianak. 2013. 